\title{
Comunicação e Aprendizagem Matemática On-line: um estudo com o Editor Científico ROODA Exata
}

Marcia Rodrigues Notare

Orientadora: Patrícia Alejandra Behar

Data da defesa: 06 de julho de 2009

Este trabalho discute as possibilidades de comunicação e aprendizagem de Matemática em ambientes virtuais de aprendizagem. Para que esses processos ocorram, são necessárias ferramentas que possibilitem a utilização de símbolos, fórmulas e expressões, pois a Matemática pode ser entendida como uma linguagem formada por uma simbologia própria. Esta linguagem precisa ser dominada e utilizada para que ocorra uma boa comunicação e expressão. Este suporte à linguagem científica deve estar presente nos mais diversos meios de comunicação e interação on-line, como fórum de discussão, bate-papo, e-mail, mensagens instantâneas, entre outros. Entretanto, ainda são poucos os ambientes virtuais de aprendizagem que permitem a comunicação científica a distância. Para possibilitar essa nova forma de comunicação on-line, este trabalho projetou e desenvolveu um editor científico, denominado ROODA Exata. Trata-se de uma ferramenta que se encontra integrada às diferentes funcionalidades síncronas e assíncronas oferecidas pelo ambiente virtual de aprendizagem ROODA. Seu objetivo é possibilitar a comunicação na área das ciências exatas, de forma rápida e precisa. Para analisar e validar o ROODA Exata, utilizou-se o ROODA como ambiente de apoio extra-classe em uma turma de Cálculo Diferencial, na modalidade presencial. As interações dos alunos neste ambiente serviram como fonte de dados para a análise. Assim, foram analisados os processos cognitivos desencadeados pelas interações no ROODA, à luz da teoria do desenvolvimento cognitivo de Piaget, e o processo de comunicação e aprendizagem ocorrido no ambiente. A pesquisa evidenciou que o editor ROODA Exata potencializa a comunicação matemática on-line e que, sem sua utilização, muitos debates seriam inviabilizados, pela complexidade das expressões matemáticas utilizadas. Além disso, os estudos realizados mostram que o processo de aprendizagem de Matemática pode ser desencadeado pelas trocas ocorridas em ambiente virtual. Estas trocas podem ocorrer a partir de atividades que priorizem a participação ativa dos alunos na resolução de problemas, valorizando ações como argumentação, justificativa, análise do percurso do raciocínio, entre outras.

Palavras-chave: Ambiente de aprendizagem. Ambiente virtual. Ensino à distância. Matemática. Rede cooperativa de aprendizagem.

Referência:

NOTARE, Marcia Rodrigues. Comunicação e Aprendizagem Matemática On-line: um estudo com o Editor Científico ROODA Exata. Orientadora: Patrícia Alejandra Behar. 2009. Tese (doutorado) Programa de Pós-Graduação em I nformática na Educação, Centro de Estudos Interdisciplinares em Novas Tecnologias da Educação, Universidade Federal do Rio Grande do Sul, 2009, Porto Alegre. 